\title{
CdS nanoparticles of different lengths induce differential responses in some of the liver functions of mice
}

\author{
Li QZ1, Sun $\mathrm{J}^{1}$, Shen $\mathrm{HT}^{2}$, Jia $\mathrm{SF}^{2}$, Bai $\mathrm{DS}^{1}$, Ma D ${ }^{1}$ \\ School of Public Health, North China University of Science and Technology, Tangshan, Hebei, 063000, PR China. \\ 15081650349@163.com
}

\begin{abstract}
Cadmium sulfide nanoparticles (CdS NPs) are one of important nanoparticle materials which are widely used in photoelectric production, but their potential health hazard to the liver is not clear. This study is aimed at exploring the possible mechanisms of liver injury induced by CdS NPs. Male mice were treated with nanoparticles of 110-130 nm and 80-100 nm cadmium sulfide. The main methods were based on detecting the vigor of superoxide dismutase (SOD) and glutathione (GSH), and content of malondialdehyde (MDA) in both blood and liver tissues as well as on observing the pathological changes in liver tissue. CdS NPs suppressed the activity of SOD and GSH, and increased the serum MDA content $(p<0.05)$; both effects were observed together in liver tissues of $80-100 \mathrm{~nm}$ group $(\mathrm{p}<0.05)$ and were accompanied by an obviously inflammatory response. CdS NPS induced oxidative damage and inflammatory response in liver tissue, which may be an underlying mechanism for its pulmonary toxicity. Additionally, the toxicity of CdS NPs was closely related to the size of nanoparticles. Pathological results showed that the hepatotoxicity of shorter CdS NPs is greater than that of longer CdS NPs (Tab. 6, Fig. 3, Ref. 20). Text in PDF www.elis.sk.

KEY WORDS: cadmium sulfide nanoparticles, oxidative damage, inflammation.
\end{abstract}

\section{Introduction}

Nanomaterials are defined as substances which have one or more external dimensions in the nanoscale $(1-100 \mathrm{~nm})$. These materials are being used increasingly for commercial purposes such as fillers, opacifiers, catalysts, semiconductors, cosmetics, microelectronics, and drug carriers (1). Owing to their high physical and chemical activity, nanoparticles are applied not only in industry but also in science. However, their high physical and chemical activity points to their potential for being highly biologically active. Furthermore, the possibility of novel biological effects of nanoparticles is not negligible (2).

$\mathrm{CdS}$ is a kind of typical II - VI semiconductor with very good photoelectric properties within the range of the visible light wavelength. With the reduction in size and dimension, CdS nanomaterials exhibit many optical, electrical and nonlinear optical properties different from their block or thin film materials. For example, the effect of quantum size changes the energy level of CdS nanoparticles, widens the energy gap, and moves the absorption and emission spectrum to the short-wave direction (3). The surface effect changes the atomic transport and configuration of $\mathrm{CdS}$ nanoparticles, as well as spin conformation of the surface

${ }^{1}$ School of Public Health, North China University of Science and Technology, Tangshan, Hebei, China, and ${ }^{2}$ North China University of Science and Technology Affiliated Hospital, Tangshan, Hebei, China

Address for correspondence: Ma D, School of Public Health, North China University of Science and Technology, Tangshan, Hebei, 063000, PR China. electron and electronic energy spectrum (4). When they enter the ecological environment or organisms, they can trigger a special biological effect, and have a negative impact on the environment and human health. In the process of research, development, production and application of nanometer materials, the research of biological safety of nanomaterials attracted the attention of many scholars (5-7). Existing research shows that nanomaterials can cause toxic damage at all levels, i.e. from genes and proteins, through subcellular and cellular structures, to the entire organism $(8-10)$. The research of the biological safety of nanomaterials is still in its early stage, and because there are many different kinds of nanometer materials with different physical and chemical properties, the knowledge of toxicity effect and safety evaluation of nanometer material is quite limited.

Therefore, the aim of this study was to find out whether nanoparticles of different sizes induce toxicity in mice as well as to elucidate the possible mechanism and consequently to be able to provide clues for disease prevention and control. We used CdS NPs, a representative material of nanoparticles as a tested substance, and tested some oxidative damage-related indexes including superoxide dismutase (SOD), glutathione (GSH) and malondialdehyde (MDA) in mice' serum and liver tissue (11-13); further more we observed the related morphological changes in the liver tissue.

\section{Materials and methods}

Two differently shaped nanorod CdS NPs, namely CdS1 and CdS2 differing in length (110-130 nm, 80-100 nm, respectively) at equal diameter $(20 \sim 30 \mathrm{~nm})$ with high purity were provided 
by College of Environmental Science and Engineering, Nankai University.

We added $0.30 \mathrm{~g}$ dihydratate cadmium chloride $\left(\mathrm{CdCl}_{2} \cdot 2\right.$ $\left.\mathrm{H}_{2} \mathrm{O}\right)$ powder and $0.40 \mathrm{~g}$ of thiourea $\left(\mathrm{CH}_{4} \mathrm{~N}_{2} \mathrm{~S}\right)$ in volume of 50 $\mathrm{ml}$ PTFE lining, while the reagents used in the experiment were not processed any further. Then we added $38 \mathrm{ml}$ ethylenediamine $\left(\mathrm{C}_{2} \mathrm{H}_{8} \mathrm{~N}_{2}\right)$ and $2 \mathrm{ml}$ of distilled water, while stirring until homogeneous solution was formed. Then we put the lining into high pressure reaction kettle, let it stand in the oven (without shaking or mixing) at a constant temperature of $150{ }^{\circ} \mathrm{C}$, and removed the kettle after $24 \mathrm{~h}$ of reaction to let it to cool to room temperature. To remove the surfactant and organic impurities, the yellow precipitate was washed with distilled water and then with ethanol several times. Then we put the CdS product into in the drying oven and after drying, we got the CdS 1 samples.

We added $0.26652 \mathrm{~g}$ trihydrate cadmium acetate $\left[\left(\mathrm{CH}_{3} \mathrm{COO}\right)_{2} \mathrm{Cd} \cdot 3 \mathrm{H}_{2} \mathrm{O}\right]$ powder and $0.242320 \mathrm{~g} / \mathrm{L}$-cysteine $\left[\mathrm{C}_{3} \mathrm{H}_{7} \mathrm{NO}_{2} \mathrm{~S}\right]$ in volume of $50 \mathrm{ml}$ PTFE lining. Then we added $16 \mathrm{ml}$ ethanol amine $\left(\mathrm{C}_{2} \mathrm{H}_{7} \mathrm{NO}\right)$ and $24 \mathrm{ml}$ of distilled water into one blender, put the lining into high pressure reaction kettle, let it stand in the oven (without shaking or mixing) at a constant temperature of $180{ }^{\circ} \mathrm{C}$. We removed the kettle after $24 \mathrm{~h}$ of reaction and let it to cool to room temperature. To remove the surfactant and organic impurities, the yellow precipitate was washed with distilled water and then with ethanol several times. Then we put the CdS product into in the drying oven and after drying, we got the CdS2 samples.

Pure $\left(\mathrm{CH}_{3} \mathrm{COO}\right)_{2} \mathrm{Cd} \cdot 3 \mathrm{H}_{2} \mathrm{O}$ was purchased from Chemistry Technological Co., Ltd. (Tianjin, China). L-cysteine $\left[\mathrm{C}_{3} \mathrm{H}_{7} \mathrm{NO}_{2} \mathrm{~S}\right]$ was purchased from Shanghai Yiteng Biological Science and Technology Co., Ltd. (Shanghai, China). Pure ethanol amine was purchased from Shanghai Mindray Chemistry Technology Co., Ltd. (Shanghai, China). All chemicals were guaranteed reagents. SOD, GSH and MDA assay kits were all obtained from Nanjing Jiancheng Bioengineering Research Institute (Nanjing, China).

\section{Animal rearing and treatment}

As the main aim was to test whether CdS NPs could induce liver toxicity without being focused on gender differences, male mice only were employed in this study. Thirty adult specific-pathogenfree (SPF) ICR mice, body weight (BW) 22-25 g, were bought from the Laboratory Animal Center of North China University of Science and Technology. The mice had free access to water and feed; adaption to the feed took place during one week preceding the treatment. Then the mice were randomly divided into three groups, namely $80-100 \mathrm{~nm}$ group (BW $23.8 \pm 1.2 \mathrm{~g}$ ), 110-130 nm group (BW $23.2 \pm 1.3 \mathrm{~g}$ ) and control group (BW $24.2 \pm 0.8 \mathrm{~g}$ ), while each group comprised 10 mice. Mice were lightly anesthetized by inhalation of diethyl ether and injected with two kinds of CdS NPs suspension, $10 \mathrm{mg} / \mathrm{Kg} \mathrm{BW}$ in $1 \mathrm{ml}$, into the enterocoelia. The injection was carried out every other day, 15 times in total. The control group was injected with $1 \mathrm{ml}$ of sterilized physiological saline into the enterocoelia. After the last injection, the weight of mice was recorded and then each mouse was killed, $1 \mathrm{ml}$ of blood and total liver tissue were collected. The specimens were stored at $-80^{\circ} \mathrm{C}$ and the liver tissues were fixed in formaldehyde fluid for histopathologic examination.

\section{The general situation and the coefficient of the liver}

We observed mice as to their eating and drinking patterns, their fur luster and mental state and compared their body weight. After the mice had been sacrificed, the liver tissues of each mouse were weighed on electronic scales. Then the formula (liver coefficient $=$ total liver wet weight/body weight x $100 \%$ ) was used to calculate the viscera coefficient.

\section{The content of Cd in whole blood and liver tissue}

After taking $0.2 \mathrm{ml}$ of whole blood and $1.0 \mathrm{~g}$ of liver tissue of all mice from all three groups, they were placed in respective conical flasks, and perchloric acid, $1 \mathrm{ml}$, and nitric acid, $4 \mathrm{ml}$, were added. The samples were left there for $12 \mathrm{~h}$ for nitrification to take place. Then, they were put on an electrothermal board and left there for 4-5 h to nitrify. After cooling, dilute nitric acid ( $1 \%$ ) was added and volume was metered to $10 \mathrm{ml}$; then they were placed in the dark to measure the cadmium levels in serum and liver tissue using the 7500 type inductively coupled plasma atomic emission spectrometry (ICP-MS) analyzer (Agilent, Santa Clara, USA). The working conditions of ICP-MS were as follows: emission power, $1420 \mathrm{w}$; frequency, 27.12; atomization pressure, 32Ibf/in2; auxiliary gas flow, $1.08 \mathrm{~L} / \mathrm{min}$; injection speed, $1.85 \mathrm{ml} /$ min; dilute nitric acid ( $2 \%$ ) flushing time, $1 \mathrm{~min}$; ultrapure water flushing time, $1 \mathrm{~min}$.

\section{Determination of oxidation damage in serum and liver tissue}

About $1.0 \mathrm{~g}$ of frozen liver tissue in $9 \mathrm{ml}$ of homogenization buffer $(0.9 \%$ sodium chloride) was homogenized on ice by a homogenizer (FA25, FLUKO equipment Shanghai Co., Ltd.) for $10 \mathrm{~s}$ at $8000 \mathrm{rpm}$. The homogenate was centrifuged at $4000 \mathrm{rpm}$ for $15 \mathrm{~min}$ at $4{ }^{\circ} \mathrm{C}$ and the supernatant was used for analysis. The SOD and GSH dynamics were measured using SOD and GSH assay kits, respectively for serum and homogenate of liver tissue according to the instruction. MDA content was measured by MDA assay kit as well.

\section{The determination of hematology indexes}

After the mice had been infected and killed, their blood was blended in $0.5 \mathrm{ml}$ anticoagulant tube. The detected f hematology indexes included red blood cells (RBC), average red blood cell volume (MCV), mean red blood cell hemoglobin concentration (MCHC), white blood cells (WBC), etc.

\section{Determination of the impact on the function of liver}

Mice blood creatinine $(\mathrm{Cr})$, urea nitrogen (BUN), alanine aminotransferase (ALT), aspartate aminotransferase (AST) and other indicators were measured to determine whether the cadmium sulfide nanoparticles had an impact on the function of liver in mice.

\section{Assessment of liver ultrastructure and histopathology}

Hepatic tissue was conventionally fixed in $2.5 \%$ glutaraldehyde solution, dehydrated, penetrated, ultra-thin sliced and elec- 
tron-stained. Ultrastructure changes were observed with a transmission electron microscope (TEM, Hitachi H-7650).

The liver tissue was taken out of $10 \%$ formaldehyde, regularly dehydrated, embedded in transparent paraffin, sectioned and dewaxed. Staining with hematoxylin-eosin (HE) staining was followed by dehydration and transparent sealing; liver histopathology was observed under light microscope and photos were taken.

\section{Statistical analysis}

All data were analyzed using one-way univariate analysis of variance (ANOVA), which was followed by LSD (equal variances assumed or homogeneity of variance after variable transformation) or Dunnett's T3 (equal variances not assumed after variable transformation justification) for post hoc test between groups using Statistical Package for Social Sciences (SPSS package version 16.0) software (SPSS, Chicago, IL, USA). The results were represented as mean $\pm \mathrm{SD}$. All tests were two-sided, and $\mathrm{p}<0.05$ was considered statistically significant.

\section{Results}

\section{Characterization of CdS nanoparticles}

The morphology of the CdS sample was examined by transmission electronmicroscopy. Figure 1a shows a typical TEM image from which uniform nanoparticles with average diameter of $20-30 \mathrm{~nm}$, length of $110-130 \mathrm{~nm}$ and $80-100 \mathrm{~nm}$, respectively (calculated with ImageJ software) could be clearly seen.

\section{The general condition and the liver coefficient}

Mice from control group presented with a lustrous fur and more autonomic activities compared to treated mice. Compared with control group and 110-130 nm group, mice in the 80-100 nm group had less autonomic activities, were markedly listless, had a slowed response, decreased food and water consumption, lacked fur luster, suffered hair loss, and the surface of their paw skin was coarse. The body weights were compared between three groups, and the differences were statistically significant (Tab. 1) $(\mathrm{p}<0.05)$. The liver coefficients of $110-130 \mathrm{~nm}$ and $80-100 \mathrm{~nm}$ groups $(68.36$ $\pm 1.21 ; 63.06 \pm 1.09$; mean $\pm \mathrm{SD}, \mathrm{n}=14$ ) were significantly higher than those in the control group $(50.54 \pm 5.23$; mean $\pm \mathrm{SD}, \mathrm{n}=14)$; the difference is statistically significant $(\mathrm{p}<0.05)$.
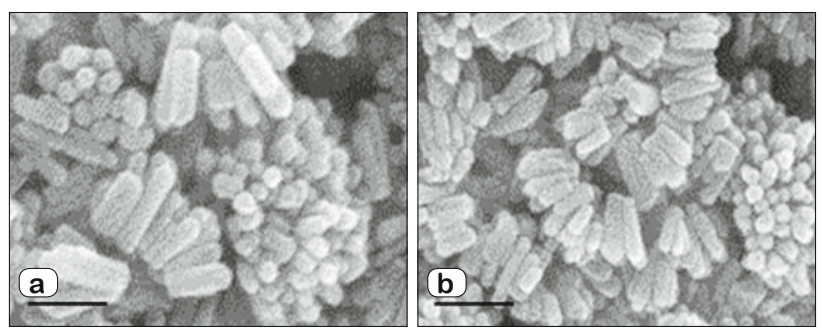

Fig. 1. Characterizations of CdS nanoparticles. (a) CdS 1: Diameter: $20 \sim 30 \mathrm{~nm}$ and length: 110-130 nm, and (b) CdS2: Diameter: $20 \sim 30$ $\mathrm{nm}$ and length: $80-100 \mathrm{~nm}$. Scale bar $=100 \mathrm{~nm}$.
Tab. 1. Effects of CdS nanoparticles on body weight loss and coefficients of liver.

\begin{tabular}{lccc}
\hline Group & $\mathrm{n}$ & Body weight increase $(\mathrm{g})$ & Liver $(\mathrm{mg} / \mathrm{g})$ \\
\hline Control & 10 & $5.028 \pm 0.241$ & $50.542 \pm 5.223$ \\
$110-130 \mathrm{~nm}$ & 10 & $0.516 \pm 0.322$ & $63.096 \pm 1.049$ \\
$80-100 \mathrm{~nm}$ & 10 & $-1.214 \pm 0.153$ & $68.376 \pm 1.215$ \\
\hline
\end{tabular}

Tab. 2. Comparison of cadmium levels in whole blood and liver tissue (mean \pm SD, $n=14)$.

\begin{tabular}{lcc}
\hline Groups & Blood cadmium $(\mathrm{mg} / \mathrm{mL})$ & Liver cadmium $(\mathrm{mg} / \mathrm{g})$ \\
\hline Control & $2.246 \pm 0.054$ & $2.007 \pm 0.043$ \\
$110-130 \mathrm{~nm}$ & $12.706 \pm 0.168^{*}$ & $26.560 \pm 0.131^{*}$ \\
$80-100 \mathrm{~nm}$ & $16.731 \pm 0.321^{* \#}$ & $40.622 \pm 0.408^{* \#}$ \\
\hline
\end{tabular}

Note: compared with the control group, $* \mathrm{p}<0.001$; compared with the110-130 nm group, \# $\mathrm{p}<0.05$

Tab. 3. Effects of CdS NPs on MDA, SOD and GSH-Px in serum.

\begin{tabular}{lcccc}
\hline Groups & $\mathrm{n}$ & $\begin{array}{c}\text { MDA } \\
\text { (nmol/mgprot) }\end{array}$ & $\begin{array}{c}\text { SOD } \\
\text { (U/mgprot) }\end{array}$ & $\begin{array}{c}\text { GSH-Px } \\
\text { (U/mgprot) }\end{array}$ \\
\hline Control & 10 & $6.496 \pm 1.204$ & $125.497 \pm 11.502$ & $553.728 \pm 30.488$ \\
$110-130 \mathrm{~nm}$ & 10 & $7.891 \pm 1.109^{*}$ & $115.902 \pm 5.203^{*}$ & $522.476 \pm 23.685^{*}$ \\
$80-100 \mathrm{~nm}$ & 10 & $9.867 \pm 3.148^{*}$ & $104.894 \pm 10.575$ & $510.793 \pm 7.324^{*}$ \\
\hline
\end{tabular}

Note: compared with the control group, $* \mathrm{p}<0.005$

Tab. 4. Effects of CdS NPs on MDA, SOD and GSH-Px in liver.

\begin{tabular}{lcccc}
\hline Groups & $\mathrm{n}$ & $\begin{array}{c}\text { MDA } \\
(\mathrm{nmol} / \mathrm{mgprot})\end{array}$ & $\begin{array}{c}\text { SOD } \\
(\mathrm{U} / \mathrm{mgprot})\end{array}$ & $\begin{array}{c}\text { GSH-Px } \\
(\mathrm{U} / \mathrm{mgprot})\end{array}$ \\
\hline Control & 10 & $8.876 \pm 1.586$ & $424.763 \pm 37.310$ & $701.758 \pm 62.821$ \\
$110-130 \mathrm{~nm}$ & 10 & $12.324 \pm 2.765^{*}$ & $378.745 \pm 46.824^{*}$ & $591.095 \pm 52.025^{* *}$ \\
$80-100 \mathrm{~nm}$ & 10 & $14.431 \pm 1.547^{*}$ & $372.783 \pm 25.607^{*}$ & $549.068 \pm 22.579^{* * \#}$ \\
\hline
\end{tabular}

The cadmium contents in mice' whole blood and liver tissues

For all groups, the contents of cadmium in mice' whole blood and liver tissues are shown in Table 2. Compared with control group, the cadmium levels were significantly higher in CdS NPs-treated mice' blood and liver tissues $(\mathrm{p}<0.001)$. The cadmium contents in mice' whole blood and liver tissues in the 80-100 $\mathrm{nm}$ group were significantly higher than in the $110-130 \mathrm{~nm}$ group $(110-130 \mathrm{~nm} ; \mathrm{p}<0.05)$

The activity of SOD and GSH and MDA levels in mice' serum

The results of the SOD and GSH activity and MDA levels in mice' serum are shown in Table 3. Compared with the control group, the SOD and GSH activities in serum in 110-130 nm and $80-100 \mathrm{~nm}$ groups were significantly decreased $(\mathrm{p}<0.05)$. The serum SOD and GSH activity in $80-100 \mathrm{~nm}$ group were lower than in $110-130 \mathrm{~nm}$ group $(\mathrm{p}<0.05)$. The MDA levels in serum of 80-100 nm group were obviously higher than those in the control group and 110-130 nm group $(\mathrm{p}<0.05)$.

The activity of SOD and GSH and MDA levels in mice'liver tissue

Results are shown in Table 4. Compared with the control group, SOD and GSH activity in the liver tissue of mice from 30$\mathrm{nm}$ group were lower than those in the control group $(\mathrm{p}<0.01$ and 
Tab. 5. The impacts of CdS NPs on the RBC, MCV, MCHC and WBC of mice $(\bar{\chi}+\mathrm{s})$.

\begin{tabular}{lcccc}
\hline Groups & $\mathrm{n}$ & $\mathrm{RBC}\left(10^{12} / \mathrm{L}\right)$ & $\mathrm{MCHC}(\mathrm{g} / \mathrm{L})$ & $\mathrm{MCV}(\mathrm{FL})$ \\
\hline Control & 10 & $4.244 \pm 0.104$ & $403.723 \pm 9.027$ & $44.596 \pm 1.325$ \\
$110-130 \mathrm{~nm}$ & 10 & $4.091 \pm 0.082$ & $381.751 \pm 5.642$ & $41.952 \pm 0.796$ \\
$80-100 \mathrm{~nm}$ & 10 & $3.400 \pm 0.121$ & $423.435 \pm 3.541$ & $40.421 \pm 0.557$ \\
\hline
\end{tabular}

Note: compared with the control group, ${ }^{*} \mathrm{p}<0.005$

Tab. 6. The impacts of CdS NPs on the Cr, BUN, ALT and AST of mice.

\begin{tabular}{llccc}
\hline Groups & $\mathrm{n}$ & $\mathrm{Cr}(\mu \mathrm{mol} / \mathrm{L})$ & BUN $(\mathrm{mmol} / \mathrm{L})$ & ALT $(\mathrm{U} / \mathrm{L})$ \\
\hline Control & 10 & $44.362 \pm 4.183$ & $9.913 \pm 1.474$ & $43.142 \pm 18.983$ \\
$110-130 \mathrm{~nm}$ & 10 & $62.281+21.142$ & $16.770+7.631$ & $53.622+16.224$ \\
$80-100 \mathrm{~nm}$ & 10 & $46.452+3.734$ & $20.614+10.782$ & $51.044+11.493$ \\
\hline
\end{tabular}

Note: compared with the control group, $* \mathrm{p}<0.005$
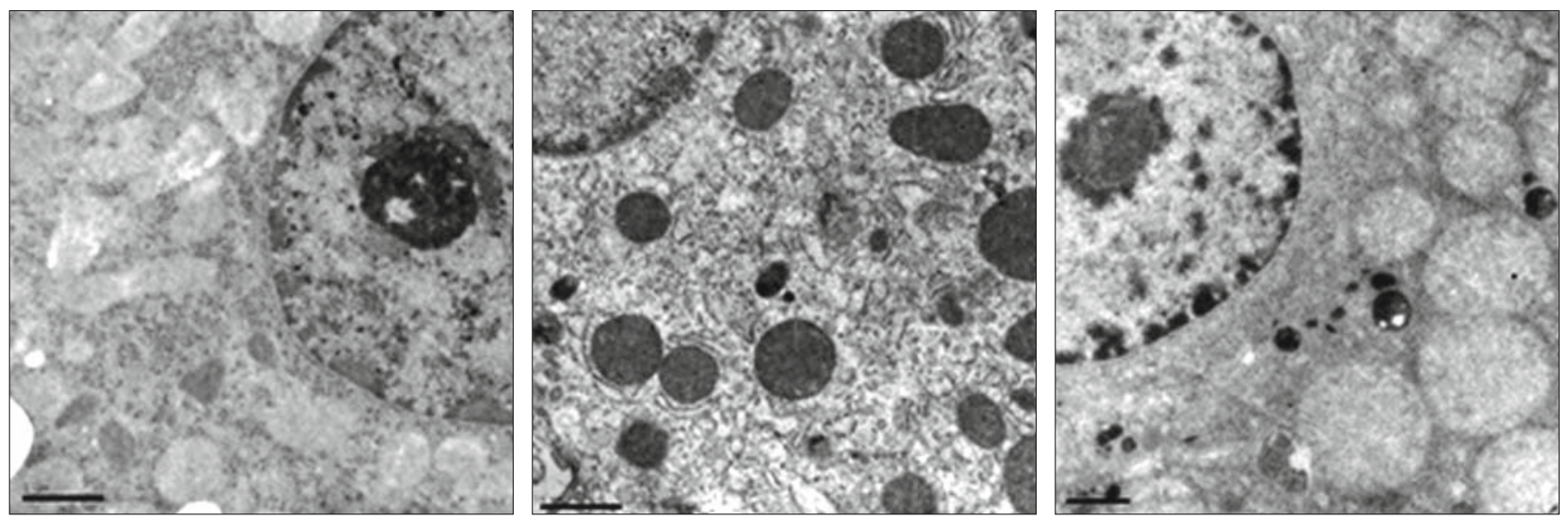

Fig. 2. Effect of CdS NPs on hepatic ultrastructure in the liver tissue (left: control group, middle: CdS1 group, right: CdS2 group).
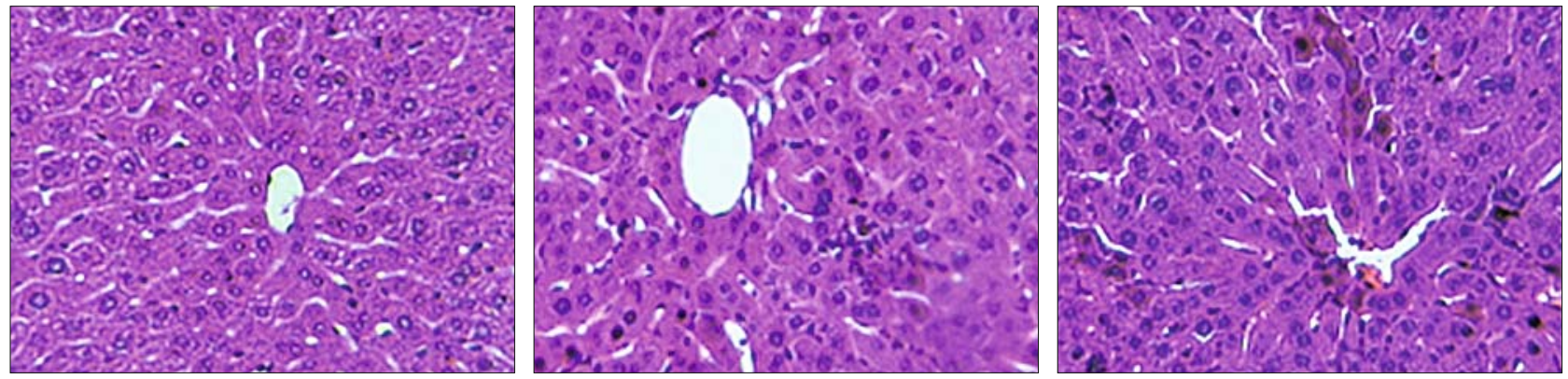

Fig. 3. The alteration of liver tissue pathological morphology of mice induced by CdS NPs. (left: control group, middle: CdS1 group, right: CdS2 group).

$\mathrm{p}<0.05$, respectively), while the MDA levels were significantly higher than those in the control group $(\mathrm{p}<0.05)$.

The impacts ofCdSNPs on the RBC, MCV,MCHCand WBCofmice

Compared with the control group, the index of RBC and MCV was reduced in CdS-treated groups, while the WBC significantly increased; compared with the control group, the index of WBC in CdS-treated groups was significantly different $(\mathrm{p}<0.05)$ as shown in Table 5.

The impacts of CdS NPs on the Cr, BUN, ALT and AST of mice

Compared with the control group, the total number of white blood cells in mice from CdS-treated groups increased significantly, the number of red blood cells decreased, and the average red blood cell volume and average hemoglobin concentration decreased. Table 6 shows the concentration of urea nitrogen, creatinine, AST and ALT. For the ratio of concentration of AST and ALT, the difference between the CdS-treated group and control group was significant $(\mathrm{p}<0.05)$; for the ratio of urea nitrogen and creatinine, there was no obvious difference between control group and $80-100 \mathrm{~nm}$ group $(\mathrm{p}>0.05), 110-130 \mathrm{~nm}$ group had statistical significance $(\mathrm{p}<0.05)$.

Effect of CdS NPs on cellular ultrastructure of liver in mice

As shown in Figure 2, there was clear hepatic caryotheca, large nucleolus and mitochondria in liver tissue from control group. CdS NPs caused hepatic ultrastructure changes including dissolved hepatic parenchyma, swollen mitochondria vacuoles, 
accumulation of chromatin pieces, shrunken nuclei, disappearance of membranes of swollen mitochondria, and nuclear apoptosis in liver tissue of mice.

\section{Morphological assessment of liver tissue pathology}

HE stained sections of rat liver tissues were examined under light microscopy to observe the pathological changes. The representative results are shown in Figure 3. Compared with the controls, CdS NPs-treated groups had obvious inflammatory changes, the liver cells of mice in control group were radiantly arranged around the lobular central vein as axis, the contour was clear in form of polygons. In 80-100 nm group, the diffuse edema of liver cells was of grade III, the liver plate was in disordered arrangement, the liver cells were swollen, and sporadic and focal inflammatory cell infiltration could be found, mainly with phagocytic cells, neutrophils and a few of lymphocytes. In 110-130 nm group, the liver cells were diffusely edematous, the liver plate was in disordered arrangement, liver cells were swollen, , and sporadic and focal inflammatory cell infiltration could be found, mainly with phagocytic cells, neutrophils and a few of lymphocytes.

\section{Discussion}

The aim of our study was to investigate the effects of exposure to CdS NPs on liver tissues such as antioxidant barrier (GSH and ROS concentration), and inflammation.

Viscera coefficient is a ratio of certain organs and their body weight of the experimental animals. An increase in viscera coefficient indicates congestion, edema, or proliferous hypertrophy of the viscera; a decrease in coefficient indicates atrophy and other degenerative changes of the viscera. Wang (14) has found out that the liver coefficient of female mice was significantly higher than that in the control group after $80 \mathrm{~nm}$ and $25 \mathrm{~nm} \mathrm{TiO}_{2}$ treatment by lavage canister, and this may be due to the inflammatory response induced by $\mathrm{TiO}_{2}$. The experiment also revealed that the viscera coefficient obviously changes after CdS NPs treatment.

The liver is the most important detoxification organs of animals and maintains life activities and metabolism in steady state. Previous studies show that nano-titanium dioxide can accumulate in the liver, kidney, while liver and kidney are the main target organs of nano-titanium dioxide in organisms (15). This study found out that after intraperitoneal injection of 80-100 nm and 110-130 $\mathrm{nm}$ CdS NPs, the Cd content in mice' liver increased obviously, and the rise in $\mathrm{Cd}$ content became the material basis for the damage to the body.

MDA is the final product in the process of scavenging free radicals of lipid peroxidation in vivo and it reflects the damage of the tissue. An increase in MDA content of CdS NPs-treated liver tissues can change the fluidity, crosslinking, structure and function of cell membrane, but also can increase the brittleness and eventually lead to cell and body damage (16). SOD and GSH-Px are the main components in intracellular lipid peroxidation enzyme resistance protection system; they can protect cells from the damage caused by lipid peroxidation. In this study, the MDA content in serum from mice exposed to CdS NPs by intraperitoneal injection was increased while SOD and GSH-Px activity decreased. The latter results showed that CdS NPs produced oxidative damage to the body's blood system, and decreased its antioxidant capacity.

Likewise, the MDA content increased, the activity of SOD and GSH-Px decreased in the liver from CdS NPs-treated groups, which showed that different sizes of CdS NPs bring about a corresponding oxidative damage to the liver, which was also confirmed by the change in ALT and AST levels in serum from CdS NPs-treated groups. Histological results showed that hepatocyte edema and necrosis in liver tissues was more obvious in CdS NPstreated mice compared with control. Accordantly, former studies (14) have also found the same pathological changes. This biological impact of CdS NPs may be due to the smaller size of particles, larger specific surface area, and thus more active points of contact with the liver. With the aggregation of particles, they deposit in tissues and organs. Although the toxicity of nanomaterials cannot simply be explained by their small size, it is certain that the size of CdS NP size influences the inflammation response and apoptosis in vivo, because the smaller the particles' size in tissues, the more difficult it becomes for macrophage and other immune cells to eliminate them. From the viewpoint of molecular biology, active oxygen free radical $\left(\mathrm{O}^{-2}\right)$ may be generated excessively in contact with nanoparticles, thus overloading the antioxidant system and resulting in functional impairment. The ALT and AST levels in serum of CdS NPs-treated groups were significantly higher than in the control group in this study, which suggests that the function of the liver can be damaged after the CdS NPs enter the human body. The abundant accumulation of $\mathrm{Cd}$ in the liver may be the basis of the damage.

The pathological results showed that the damage to the hepatocytes after treatment with two different sizes of CdS NPs particles was obvious, produced a large area of edema and dot necrosis. Furthermore, $80-100 \mathrm{~nm}$ CdS NPs induced more serious injuries than $110-130 \mathrm{~nm} \mathrm{CdS}$ in the liver, which could be seen as change in cellular morphology and was related to the size of nanoparticles. The results of lung toxicity study of polytetrafluoroethylene (PTFE) showed that after $15 \mathrm{~min}$ of exposition of rats to PTFE dust (dust particle average $18 \mathrm{~nm}$ in diameter, mass concentration of $50 \mathrm{ug} / \mathrm{m}^{3}$, the equivalent of $5 \times 10^{5}$ particles $/ \mathrm{cm}^{3}$ ), the dust particles deposited in alveoli and caused severe acute lung injury (17). Similarly, Johnston et al (18) found out that when PTFE accumulated and the grain size aggregates increased over $100 \mathrm{~nm}$, the toxicity decreased.

These studies showed that the toxicity of nanometer material is related closely to its particle size (surface area); the smaller the particle size of nanometer materials, the larger surface area leads to stronger toxicity. This may be associated with the surface effect of nanometer particles due to the increase in specific surface area, surface binding energy and significant enhancement of chemical activity of nanoparticles, while the rate of the reaction with the body also increases accordingly. However, Wang et al (19) reported that the degree of the damage to liver caused by zinc nanoparticles $(58 \mathrm{~nm})$ is lower than that caused by zinc micron particles. Warheit et al (20) reported nano and micro sizes of titanium dioxide particles induced the same degree of rat lung inflammation and 
cell damage, showing that the toxic effect induced by nanometer titanium dioxide particles had no significant correlation with the size of titanium dioxide particles. These results showed that the relationship between the particle size of nanomaterials and the damage was still not very clear, and contradictory.

The comparison of damage effects on mice treated with $\mathrm{CdS}$ sized either $80-100 \mathrm{~nm}$ or $110-130 \mathrm{~nm}$ showed that the viscera coefficient, weight change, content of cadmium in blood and liver tissue, MDA, SOD and GSH-Px activity in serum and liver tissue, function indicators of blood and liver were significantly lower in the 110-130 nm-treated group as well as that the trend of the damage effect on mice increased with the size of CdS particles and as a result, the size of CdS nanoparticles was correlated with the damage. Nevertheless, further research is still needed.

\section{References}

1. Nel A, Xia T, Mädler L, Li N. Toxic potential of materials at the nanolevel. Science 2006; 311: 622-627.

2. Horie M, Kato H, Fujita K, Endoh S, Iwahashi H. In Vitro Evaluation of Cellular Response Induced by Manufactured Nanoparticles. Chem Res Toxicol 2012; 25: 605-619.

3. Duan X, Huang Y, Agarwal R, Lieber CM. Single-nanowire electrically driven lasers. Nature 2003; 421: 241-245.

4. Shvydka, D., Drayton, J., Compaan, A. D., Karpov, V. G. Piezoeffect and physics of cds-based thin-film photovoltaics. Applied Physics Letters 2005; 87: 567-575.

5. Kipen H M, Laskin D L. Smaller is not always better: nanotechnology yields nanotoxicology. Am J Physiol Lung Cell Mol Physiol 2005; 289: 696-697.

6. Holsapple, M. P., Farland, W. H., Landry, T. D., Monteiro-Riviere, N. A., Carter, J. M., \& Walker, N. J. Research strategies for safety evaluation of nanomaterials, part ii: toxicological and safety evaluation of nanomaterials, current challenges and data needs. Toxicol Sci 2005; 88: 12-17.

7. Borm PJ, Robbins D, Haubold S, Kuhlbusch T, Fissan H, Donaldson K, Schins R, Stone V, Kreyling W, Lademann J, Krutmann J, Warheit D, Oberdorster E. The potential risks of nanomaterials: a review carried out for ECETOC. Part Fibre Toxicol 2006; 14: 11.

8. Lam CW, James JT, McCluskey R, Hunter RL. Pulmonary toxicity of single-wall carbon nanotubes in mice 7 and 90 days after intratracheal instillation. Toxicol Sci 2004; 77: 126-134.
9. Lin W, Huang YW, Zhou XD, Ma Y. In Vitro Toxicity of Silica Nanoparticles in Human Lung Cancer Cells. Toxicol Appl Pharmacol 2006; 217: 252-259.

10. Wang $\mathbf{J} \mathbf{J}$, Sanderson B J, Wang H. Cyto- and genotoxicity of ultrafine $\mathrm{TiO}_{2}$ particles in cultured human lymphoblastoid cells. Mutat Res 2007; 628: 99-106.

11. Li, G., Feng, X., Wang, S. Effects of $\mathrm{Cu} / \mathrm{Zn}$ Superoxide Dismutase on Strain Injury-Induced Oxidative Damage to Skeletal Muscle in Rats. Physiol Res 2005; 54: 193-199.

12. Yu QY, Fang SM, Zuo WD, Dai FY, Zhang Z, Lu C. Effect of organophosphate phoxim exposure on certain oxidative stress biomarkers in the silkworm. J Econ Entomol. 2011; 104: 101-106.

13. Zhang Y1, Meng D, Wang Z, Guo H, Wang Y. Oxidative stress response in two representative bacteria exposed to atrazine. FEMS Microbiol Lett 2012; 334: 95-101.

14. Wang J, Zhou G, Chen C, Yu H, Wang T, Ma Y, Jia G, Gao Y, Li B, Sun J, Li Y, Jiao F, Zhao Y, Chai Z. Acute toxicity and biodistribution of different sized titanium dioxide particles in mice after oral administration. Toxicol Lett 2007; 168: 176-185.

15. Wang JX, Li W, Liu Y. Effects of environmental health and ecological toxicology of titanium dioxide nanometer materials. Asian J Ecotoxicol 2008; 3: 105-113.

16. Jones HB, Garside DA, Liu R, Roberts JC. The influence of phthalate esters on Leydig cell structure and function in vitro and in vivo. Exp Mol Pathol 2005; 58: 179-193.

17. Oberdorster G, Gelein RM, Ferin J, Weiss B. Association of particulate airpollution and acute mortality:involvement of ultrafine particles. Inhal Toxicol 1995; 7: 111-124.

18. Johnston CJ1, Finkelstein JN, Mercer P, Corson N, Gelein R, Oberdörster G. Pulmonary effects induced by ultrafine PTFE particles. Toxicol Appl Pharmacol 2000; 168: 208-215.

19. Wang B1, Feng WY, Wang TC, Jia G, Wang M, Shi JW, Zhang F, Zhao YL, Chai ZF. Acute toxicity of nano-andmicro-scale zinc powder in healthy adultmice. Toxicol Lett 2006; 161: 115-123.

20. Warheit DB, Webb TR, Sayes CM, Colvin VL, Reed KL. Pulmonary instillation studies with nanoscale $\mathrm{TiO}_{2}$ rods and dots in rats: toxicity is not dependent upon particle size and surface area. Toxicol Sci 2006; 91: 227-236.

Received September 24, 2017. Accepted November 2, 2017. 